\title{
How THE GERMAN CONCEPTS OF HORIZONTALISM AND PROPORTIONALITY COULD IMPROVE THE US STATE ACTION Doctrine
}

\author{
STEPHAN JAGGI
}

\begin{abstract}
The US Supreme Court has been widely criticized for inconsistencies in applying its state action doctrine. The author's thesis is that these inconsistencies are a result of the Court's focus on exceptions to the doctrine and could be overcome by a more principled application of the doctrine. The article argues that the German concepts of horizontalism, i.e. the application of constitutional individual rights to law applied in private relationships, and proportionality could contribute to a more principled application of the US state action doctrine.
\end{abstract}

\section{TABLE OF CONTENTS}

Introduction

I. The US State Action Doctrine's Inconsistencies: A Case Study

A. The Civil Rights Cases

$B$. The White Primary Cases

C. The Shopping Mall Cases

D. The Judicial Enforcement Cases

II. Critique

III. The German Concepts of Horizontalism and Proportionality

A. Horizontalism

B. Proportionality

IV. Applying Horizontalism and Proportionality to US State Action Cases

A. The US Supreme Court's Own Practice

B. More Principled Solutions with Horizontalism and Proportionality

Conclusion

\section{INTRODUCTION}

The state action doctrine is one of the most important and most controversial topics in US constitutional law. ${ }^{1}$ It is important because the state action doctrine decides whether or not constitutional rights apply in a case, ${ }^{2}$ and it is controversial because there is virtually endless criticism of the US Supreme

1. Tushnet calls it one of the most difficult topics. See Mark V. Tushnet, Weak Courts, Strong Rights: Judicial Review and Social Welfare Rights in Comparative COnstitutional LAW, 162 (2008).

2. Erwin Chemerinsky, Note, Rethinking State Action, 80 Nw. U. L. Rev. 503, 504 (1985); Louis M. Seidman \& Mark V. Tushnet, Remnants of Belief, 51 (1996); but see Frank I. Michelman, The State Action Doctrine in Global Perspectives on Constitutional Law 228 (2008). 
Court's application of the doctrine. ${ }^{3}$ The latter seems surprising because the doctrine establishes a simple rule: Individual rights apply to government action only, not to private action. ${ }^{4}$ Problems arise, however, when private actors interfere with other private actors' liberties and the Court still has the feeling that the Constitution should apply. When, for example, a political party prevents African-Americans from participating in its primaries, a company town prohibits a Jehovah's Witness from distributing religious leaflets on its sidewalks, or a private contract prevents homeowners from selling their homes to AfricanAmericans, the Court, despite the fact that only private parties interact, still thinks that, under certain circumstances, such action should be prohibited under the Constitution. To determine the exact requirements under which the Constitution applies in those cases, the Court has developed exceptions to the state action doctrine and applies individual rights to private action if the private actor either fulfills a "public function" or is sufficiently "entangled" with the government. It is these exceptions that the Court has been unable to develop and apply in a principled way.

The Court's critics either try to improve the criteria that determine whether or not a private actor must be deemed a state actor $^{5}$ or they want to completely abolish the state action doctrine and apply individual rights directly to private action. $^{6}$

My thesis is that the key to solving the problem is to neither abolish nor modify the state action doctrine, but to apply it in a more principled way. For a more principled application, I propose to integrate the German concepts of horizontalism and proportionality into the US state action doctrine. I will argue that, instead of developing exceptions to the doctrine, horizontalism would allow the Court to focus on the cases' obvious state action, the law as applied to the private relationship; the proportionality test would allow the Court to examine this law's as-applied constitutionality by balancing the conflicting individual rights at play in the specific case. Horizontalism would show that law applied in private relationships affects the individual rights of all parties involved. For example, a state trespass law enforced against protesters in a private shopping mall protects the mall owner's property at the expense of the protesters' freedom

3. See generally Stephen Gardbaum, Note, The "Horizontal Effect" of Constitutional Rights, 102 Mich. L. Rev. 387, 412 (2003); Henry J. Friendly, The Public-Private PenumbraFourteen Years Later, 130 U. PA. L. REV. 1289, 1290 (1982).

4. Laurence H. Tribe, American Constitutional Law 1688 (2d ed.1988).

5. See Louis Henkin, Note, Shelley v. Kraemer: Notes for a Revised Opinion, 110 U. PA. L. REv. 473, 481 (1962); Thomas P. Lewis, The Meaning of State Action, 60 Colum. L. Rev. 1083 (1960); Louis H. Pollak, Racial Discrimination and Judicial Integrity: A Reply to Professor Wechsler, 108 U. PA. L. REV. 1, 13 (1959).

6. Chemerinsky, supra note 2; Harold W. Horowitz, The Misleading Search for "State Action" Under the Fourteenth Amendment, 30 S. CAL. L. ReV. 208 (1957); CASS R. Sunstein, The Partial Constitution 159-60 (1993); Gardbaum, supra note 3; MARK V. Tushnet, State Action in 2020, in The Constitution IN 2020, at 69, 70, and 77 (Jack M. Balkin \& Reva B. Siegel eds., 2009). 
of speech; a court order enforcing a racially restrictive private covenant protects one party's freedom of contract at the expense of another party's right to nondiscrimination and property. The concept of proportionality then would help the Court decide whether the balance struck between the competing individual rights in the particular case remains within the limits set by the constitution. The concepts of horizontalism and proportionality would provide a framework for a principled balancing of competing individual rights and would thus contribute to solving the state action doctrine's inconsistency problem.

After demonstrating, with a case study, the inconsistencies of the Court's current application of the state action doctrine, I will give an overview of the critique of the Court's practice and will then show how the German concepts of horizontalism and proportionality would contribute to a more principled application of the US state action doctrine.

\section{THE US STATE ACTION DOCTRINE's INCONSISTENCIES: A CASE STUDY}

The following case study, which analyzes some of the Court's most important state action decisions, will reveal two core inconsistencies. First, after stating the doctrine's focus on state action and that what must be examined is that action's constitutionality, the Court often fails to apply its own doctrine. This starts as early as the Civil Rights Cases, where the Court decided without determining the relevant state action or examining its constitutionality. It becomes even more apparent in later cases, where the Court often focused not on the obvious state action and its constitutionality but on exceptions to the state action doctrine. Second, the Court has been unable to apply the exceptions in a principled way. The Court itself has admitted that there is no principled way of answering the question of government responsibility for private action and that it must be answered by sifting the facts of the specific case at hand. ${ }^{7}$ In practice, this results in the Court arbitrarily exempting some state laws from federal judicial review.

\section{A. The Civil Rights Cases}

The Court established the state action doctrine in the Civil Rights Cases $(1883),{ }^{8}$ where it examined the constitutionality of Sections 1 and 2 of the federal Civil Rights Act of 1875 granting everyone equal access to public accommodations regardless of race. ${ }^{9}$ The question was whether Congress had the authority to enact such a law. ${ }^{10}$ Based on Sec. 5 of the Fourteenth Amendment, Justice Bradley, writing for the Court, examined whether Sec. 1 and 2 of the 1875 Civil Rights Act were "appropriate legislation" to enforce Sec. 1 of the Fourteenth Amendment. ${ }^{11}$

7. Burton v. Wilmington Parking Auth., 365 U.S. 715 (1961).

8. Civil Rights Cases, 109 U.S. 3, 24 (1883).

9. Id. at 9 .

10. Id. at 10 .

11. Id. at 11 . 
Referring to the text of Sec. 1 of the Fourteenth Amendment, Bradley argued that "[i]t is State action of a particular character that is prohibited. Individual invasion of individual rights is not the subject matter of the amendment."12 Accordingly, Sec. 5 of the Fourteenth Amendment gives Congress the authority to enforce, by appropriate legislation, the prohibition of state action of a particular character, e.g. state action that denies to any person within its jurisdiction the equal protection of the laws. ${ }^{13}$ Bradley stated that Congress is authorized " $[\mathrm{t}] \mathrm{o}$ adopt appropriate legislation for correcting the effects of such prohibited State laws and State acts, and thus to render them effectually null, void, and innocuous." 14

This explanation seems to imply that legislation under Sec. 5 is not limited to directly addressing and repealing prohibited state acts but may do whatever is "appropriate" for "correcting the effects" of prohibited state acts. Bradley, however, chose a narrower interpretation and concluded that:

It [Sec. 5] does not invest Congress with power to legislate upon subjects which are within the domain of State legislation, but to provide modes of . . . redress against the operation of State laws and the action of State officers executive or judicial when these are subversive of the fundamental rights specified in the amendment. ${ }^{15}$

With respect to the scope not only of the Fourteenth Amendment but of individual rights more generally, Bradley argued:

[C]ivil rights, such as are guaranteed by the Constitution against State aggression, cannot be impaired by the wrongful acts of individuals, unsupported by State authority in the shape of laws, customs, or judicial or executive proceedings. The wrongful act of an individual, unsupported by any such authority, is simply a private wrong, or a crime of that individual; an invasion of the rights of the injured party, it is true, whether they affect his person, his property, or his reputation; but if not sanctioned in some way by the State, or not done under State authority, his rights remain in full force, and may presumably be vindicated by resort to the laws of the State for redress. ${ }^{16}$

This means that whenever there is "State authority in the shape of laws customs, or judicial or executive proceedings" supporting or sanctioning an act by a private individual interfering with another private individual's rights, individual rights do apply and they can be impaired by the state act that supports

12. Id. Sec. 1's text states: "No State shall make or enforce any law which shall abridge the privileges or immunities of citizens of the United States; nor shall any State deprive any person of life, liberty, or property without due process of law; nor deny to any person within its jurisdiction the equal protection of the laws."

13. Id..

14. Id.

15. Id.

16. Id. at 17 . 
or sanctions a private individual's invasion of the rights of the injured party. ${ }^{17}$

The Court's state action doctrine, as established in the Civil Rights Cases, may thus be summarized in the following test: (1) Is there a state act, such as a law, an executive act, or a judicial decision, that in some way supports or sanctions an act by a private individual interfering with another private individual's rights? and (2) does this state act, as applied in the specific case, violate an individual right granted by Constitution? If the answer to both questions is yes, the third question raised by Sec. 5 of the Fourteenth Amendment would be: Is the Congressional act under examination "appropriate legislation" to correct this violation?

And these are indeed the questions that Bradley started out with:

And so, in the present case, until some State law has been passed, or some State action through its officers or agents has been taken [1], adverse to the rights of citizens sought to be protected by the Fourteenth Amendment [2], no legislation of the United States under said amendment, nor any proceeding under such legislation, can be called into activity [3]. ${ }^{18}$

After formulating this three-pronged test, however, Bradley, all of a sudden, cut his inquiry short. Instead of examining whether some state law had been passed or some state action had been taken in violation of the Fourteenth Amendment, he immediately jumped to the third question and tried to determine whether the 1875 Civil Rights Act was "appropriate legislation" under Sec. 5. Writing that legislation under Sec. 5 must be adapted to the wrong, which is state action in violation of individual rights, ${ }^{19}$ Bradley concluded that, since the 1875 Civil Rights Act made no reference to state acts in violation of the Fourteenth Amendment but directly regulated individuals, it was "not corrective" but "primary and direct" and thus not covered by Sec. $5 .^{20}$

But, how could Bradley know that the 1875 Civil Rights Act was inappropriate to correct violations of individual rights by state acts without first identifying these state acts and examining if and how they violated the Fourteenth Amendment? Why can a law that is primary, direct, and does not make any reference to adverse state legislation on the subject never be corrective of such state legislation or other state action? If there had been state law or state enforcement practices that allowed restaurant owners to discriminate on the basis of race, it might have been appropriate for Congress to adopt legislation directly prohibiting such private discrimination without explicitly addressing the permissive state action. If, for example, state trespass laws provided restaurant owners with the legal means to enforce racist customer policies, it is hard to see how this discriminatory "act of an individual" was not "supported by State

17. Id.

18. Id. at 13 .

19. Id. at $13-14$.

20. Id. at $14,18-19$. 
authority in the shape of law" which, as applied in the specific case, could violate the Equal Protection Clause, and why a federal law directly obliging the restaurant owner to stop his racist behavior could never be "appropriate legislation" to enforce the Equal Protection Clause. ${ }^{21}$ Moreover, the separation of powers should give Congress some leeway to decide what legislation is "appropriate" to address the violation.

As a result of Bradley's shortcut, the Court neither mentioned nor examined other obvious state action in the case, for example the states' racially discriminatory non-enforcement of existing common law granting equal access to public accommodations to customers who complied with the general rules of good behavior. Bradley even hinted at this law by saying that he has "discussed the question presented by the law on the assumption that a right to enjoy equal accommodation and privileges in all inns . . . is one of the essential rights of the citizen which no State can abridge or interfere with." 22 States were notorious for not enforcing common law equal access rights whenever African-Americans were trying to benefit from them. ${ }^{23}$ "Systematic maladministration" of laws and state courts' refusal to enforce equal access laws are paradigmatic state acts that clearly provided "support" for the private owners' refusal to admit African-Americans to public accommodations. ${ }^{24}$ Why, in the light of such pervasive state action in violation of the Equal Protection Clause, direct regulation of private behavior could never be appropriate Bradley neither addressed nor answered.

The Court did mention that it held the Congressional act to be overly broad because "[i]t applies equally to cases arising in States which have the justest laws respecting the personal rights of citizens, and whose authorities are ever ready to enforce such laws, as to those which arise in States that may have violated the prohibition of the amendment." ${ }^{25}$ However, since the Court neither determined the relevant state action nor examined its constitutionality, it could not really tell whether the Congressional act's breadth made it indeed inappropriate to correct the effects of unconstitutional enforcement practices in many states.

Despite explicitly mentioning common law rights to equal access, even Justice Harlan's famous dissent did not address any of these shortcomings. ${ }^{26}$ Instead Harlan introduced what would later become the "public function" exception to the state action doctrine. He argued that, based on the equal access obligation, an innkeeper exercises "quasi-public" employment and that this "public nature of his employment" exposes him to the Fourteenth Amendment

21. Id. at 17 .

22. Id. at 19 .

23. United States v. Morrison, 529 U.S. 598, 625 (2000).

24. Civil Rights Cases, 109 U.S. at 19.

25. Id. at 14 .

26. Harlan refers to Judge Story's "Story on Bailments $\S \S 475-476$ ”: “An innkeeper is bound to take in all travelers and wayfaring persons, and to entertain them, if he can accommodate them, for a reasonable compensation, and he must guard their goods with proper diligence. . . If an innkeeper improperly refuses to receive or provide for a guest, he is liable to be indicted therefor. ..." Id. at 40 . 
and prohibits him from discriminating on the basis of race. ${ }^{27}$ In fact, Harlan's dissent is an early example of how justices, instead of examining the obvious state action's as-applied constitutionality, focus on exceptions to the state action doctrine.

The Civil Rights Cases, thus, not only established the state action doctrine, but are also a first example of how the Court does not properly apply it. Like the Slaughterhouse Cases, they reflect the Court's tendency at the time to protect state sovereignty at the expense of individual rights. ${ }^{28}$

Many of the Court's following state action cases display a similar lack of proper application and a focus on the doctrine's exceptions instead of the obvious state action. They also show the Court's inability to apply the exceptions in a principled way.

\section{B. The White Primary Cases}

The so-called White Primary Cases are early examples of the Court's publicfunction exception. ${ }^{29}$

The first case, Nixon v. Herndon (1927), was an easy one from a state action perspective. $^{30}$ Texas law explicitly excluded African-Americans from voting in Democratic Party primaries, and the Court briefly declared the racially discriminatory law unconstitutional under the Fourteenth Amendment's Equal Protection Clause.

The next case, Nixon v. Condon (1932), ${ }^{31}$ dealt with Texas' reaction to Herndon, a new statute that no longer explicitly excluded African-Americans from party primaries but instead granted a political party's state executive committee the authority to "determine who shall be qualified to vote ... in such political party." ${ }^{\prime 2}$ Based on this authority, the Democratic Party's state executive committee adopted a resolution limiting the right to participate in the party's primaries to whites..$^{33}$ In an attempt to defend the law's constitutionality under the Fourteenth Amendment, Texas argued that a political party is a "voluntary association" with an "inherent power" to determine its own affairs so that the new law only "restore[d] to the members of the party the power that would have been theirs if the lawmakers had been silent." ${ }^{34}$ Accordingly, Texas argued, the racebased discrimination was purely private and had nothing to do with the law or the state, which had only restored a private actor's "natural" liberty to discriminate. ${ }^{35}$

27. Id. at 41 .

28. Tushnet, supra note 6 , at 73.

29. See TRIBE, supra note 4 , at 1705-07.

30. Nixon v. Herndon, 273 U.S. 536 (1927).

31. Nixon v. Condon, 286 U.S. 73 (1932).

32. Id at $81-82$.

33. Id. at 82 .

34. Id. at 83 .

35. Id. 
The Court, in 1932, evaded this argument as well as the underlying question of whether a law that authorizes a private party to do something is state action and interferes with another private actor's liberties. Instead, it focused on a completely different point, namely the fact that it was the party committee that had acted, authorized by the new law:

Whatever our conclusion might be if the statute had remitted to the party the untrammeled power to prescribe the qualification of its members, nothing of the kind was done. Instead, the statute lodged the power in a committee, which excluded the petitioner and others of his race not by virtue of any authority delegated by the party, but by virtue of an authority originating ... in the mandate of the law. ${ }^{36}$

However, " $[\mathrm{w}]$ hatever inherent power a state political party has to determine the content of its membership resides in the state convention," not in the state committee. ${ }^{37}$ Since the state law delegated the authority to determine the right to vote in primaries to the committee instead of the convention, the Court argued, the committee's power to exclude African-Americans from party primaries came exclusively from the law, not from the party's inherent power. ${ }^{38}$

Once again, instead of examining the new state law's as-applied constitutionality, the Court asked a completely different question: Has the party committee become a state actor? The Court argued that the committee, by exercising the authority given to it by law, became "to that extent the [organ] of the State itself." 39 Therefore, the committee's exclusion of African-Americans from the party's primaries must be deemed a discriminatory state action in violation of the Fourteenth Amendment. ${ }^{40}$ A private actor's simple authorization by law sufficed to turn the private actor into a state actor.

The Court's refusal to focus on the new state law's constitutionality seems particularly surprising in light of the obvious fact that the state legislature established the new law in reaction to Herndon. What the Democratic Party Committee would do with its new legal authority became quite clear. As a result, the obvious question turned into whether the state legislature could evade the Fourteenth Amendment by simply replacing a Black Code with a facially raceneutral law that authorized the Party to continue its race-based discrimination.

The Court's only explanation for ducking this question was that it wanted to decide the case on narrow grounds. ${ }^{41}$ However, that explanation hardly justifies steering the state action doctrine away from examining the obvious state action's constitutionality and towards determining the conditions under which private action would become state action. The Court's decision seems driven by the desire to evade examining the as-applied constitutionality of the new state

36. Id. at 84 (emphasis added).

37. Id. (emphasis added).

38. Id. at 85 .

39. Id. at 88 .

40. Id. at 89 .

41. Id. at 84 . 
law - the only obvious state action in the case.

Only Justice McReynolds' dissent ${ }^{42}$ focused on the new state law as the obvious state action. He emphasized that the new law was facially race-neutral and merely "recognizes power in every political party, acting through its Executive Committee, to prescribe qualifications for membership." ${ }^{43}$ Consequently, he saw no violation of the equal protection clause.

Even though McReynolds' answer was wrong, he at least asked the right question: Was the new state law constitutional? A strong argument against the law's constitutionality, overlooked by all justices, is that by adopting the new law, the state legislature made a clear choice in favor of the party's right to selfdetermination at the expense of African-Americans' right to vote and to not be discriminated against on the basis of race. This choice was particularly evident in light of the past discriminations against African-Americans and the fact that the new law explicitly prohibited parties to discriminate against voters on the basis of former political views or affiliations. ${ }^{44}$ The decisive question, thus, would have been if the state legislature was entitled, under the federal Constitution, to make this choice. The Court ducked this question by focusing on whether the party had become a state actor.

After this evasion, it was not surprising that Texas' Democratic Party, exactly twenty-two days after Condon, started its next attempt to exclude AfricanAmericans from its primaries - this time through its convention instead of its committee. ${ }^{45}$ In Grovey v. Townsend (1935) ${ }^{46}$ the Court followed Condon and asked if the party convention, by excluding African-Americans from party primaries, had become a state actor. The Court unanimously denied this and argued that neither the primaries' comprehensive regulation ${ }^{47}$ nor the fact that Texas' election laws granted the party convention the authority to determine the eligibility for participation in party primaries turned the convention into a state actor. ${ }^{48}$ Echoing Texas' argument in Condon, ${ }^{49}$ the Court implied a convention's natural authority to announce a party's will: " $[\mathrm{N}]$ othing is shown to indicate that the regulation of the method of choosing delegates or fixing the times of their meetings was intended to take away the plenary power of conventions in respect of matters as to which they would normally announce the party's will." ${ }^{50}$ The convention's exclusion of African-Americans from party primaries was thus

42. Id. at 90, 106 (McReynolds, J., dissenting) (joined by Justices Van Devanter, Sutherland, and Butler).

43. Id. at 94 .

44. Id. at 82 (majority opinion).

45. See Condon, 286 U.S. (decided May 2, 1932); see also Grovey v. Townsend, 295 U.S. 45 (1935).

46. Grovey v. Townsend, 295 U.S. 45 (1935).

47. Id. at 49,50 .

48. Id. at 50,53 .

49. See id. at 83 .

50. Id. at 54 (emphasis added); see Condon, 286 U.S. at 83. 
constitutional.

The Court did not explicitly ask where the convention's "plenary power" to "announce the party's will" came from. Instead, the Court argued earlier that " $a$ proper view of the election laws of Texas . . required the conclusion that the Democratic Party in that state . . . has the power to determine who shall be eligible . . . to participate in the party's primaries. ${ }^{.51}$ The convention's power to exclude people from the party's primaries was thus moored in state law. Therefore, under the state action doctrine, the obvious question should have been whether such state law was constitutional if it permitted a party convention to engage in race-based discrimination. The Court neither asked nor answered this question.

In Smith v. Allwright (1944), ${ }^{52}$ the Court tackled the exclusion of AfricanAmericans from party primaries by the Texas Democratic Party Convention a second time. ${ }^{53}$ Again, the Court did not address the state election laws' as-applied constitutionality but focused on whether the Convention was a state actor instead $^{54}$ This time the Court decided that it was and overruled Grovey. ${ }^{55}$ Holding the primaries' comprehensive regulation sufficient to consider the Convention a state actor, the Court argued that "this statutory system . . . makes the party which is required to follow these legislative directions an agency of the state in so far as it determines the participants in a primary election.. ${ }^{56}$ As a state actor, the Convention had violated the Fifteenth Amendment by excluding AfricanAmericans from primaries. ${ }^{57}$ Justice Roberts' dissent pinpoints the reader's perplexity when, referring to the Court's unanimous decision in Grovey, he wrote that "[n]ot a fact differentiates that case from this except the names of the parties." ${ }^{58}$

It was more in an afterthought when the Court touched upon a central question under the state action doctrine as established in the Civil Rights Cases. The Court argued that a citizen's right to vote "is not to be nullified by a state through casting its electoral process in a form which permits a private organization to practice racial discrimination in the election. Constitutional rights would be of little value if they could be thus indirectly denied." ${ }^{59}$ For the first time since Herndon, the Court referred to the obvious state action: the state law that permitted a private party to discriminate on the basis of race. Under the state action doctrine, the Court should have examined whether this law, as applied in the specific case, violated the state's obligations under the Fourteenth and Fifteenth Amendments. The Court, however, did not further elaborate this

51. Grovey, 295 U.S. at 52 (emphasis added).

52. Smith v Allwright, 321 U.S. 649 (1944).

53. Id. at 656-57.

54. Id. at 661-62.

55. Id. at 666 .

56. Id. at 663 .

57. Id. at 666 .

58. Id. at 669 (Roberts, J., dissenting).

59. Id. at 664 (majority opinion) (emphasis added). 
thought.

The Court's failure to elaborate gave the Texas Democratic Party another shot at excluding African-Americans. The Jaybird Democratic Association (Jaybirds), a private, unregulated association, excluded African-Americans and held internal elections to determine the candidates it would endorse in Democratic Party primaries. These candidates usually won the primaries as well as the following general elections. ${ }^{60}$

In Terry v. Adams (1953), ${ }^{61}$ the Court interfered. Justice Black's opinion, joined by Justices Douglas and Burton, argued that, by holding pre-primary elections that determine the outcome of the Democratic primaries and the following general elections in Texas, the Jaybirds "[bring] into being . . . the kind of election that the Fifteenth Amendment tries to prevent." ${ }^{\circ 2}$ However, Black did not reach this conclusion by holding the Jaybirds to be state actors. Instead, Black reached this conclusion by identifying the Texas law that permitted the Jaybirds to do what they did as the obvious state action and examining its as-applied constitutionality. He emphasized that "the constitutional right to be free from racial discrimination in voting ... is not to be nullified by a state through casting its electoral process in a form which permits a private organization to practice racial discrimination in the election.",63

While Frankfurter agreed with Black, ${ }^{64}$ Justice Clark ${ }^{65}$ continued the Court's previous practice of applying the public-function exception and asked what may turn the Jaybirds into state actors. He argued that "because in fact it [the Jaybird Association] functioned as a part of the state's electoral machinery, we held it controlled by the same constitutional limitations that ruled the official general election." ${ }^{" 66}$ Picking up on this point in his dissent, Justice Minton argued that there was no evidence that the Jaybirds functioned as a part of the state's electoral machinery; instead, the Jaybirds were completely independent of the state and even of the Democratic Party, and nothing they did was in any way subject to state regulation. ${ }^{67}$ From this, he concluded, "I do not understand that concerted action of [private] individuals which is successful somehow becomes state action." ${ }^{68}$

Clarks' and Minton's arguments demonstrate the public-function exception's inconsistencies. In Condon, the legislative authorization of private behavior sufficed to find state action, in Grovey it didn't, in Smith it did, and Terry did not

60. See Terry v. Adams, 345 U.S. 461, 462-63 (1953).

61. Id. at 461.

62. Id. at 469 .

63. Id. at 466 (emphasis added) (internal quotation marks omitted).

64. Id. at $470,477$.

65. Id. at 477 (Clark, J., concurring) (joined by Chief Justice Warren and Justices Reed and Jackson)

66. Id. at 481-82.

67. Id. at 485 (Minton, J., dissenting).

68. Id. at 493 . 
even require any legislative authorization in order for one justice to consider the Jaybirds state actors. These inconsistencies contrast sharply with Black's opinion, which identifies the applied state law as state action and makes a reasonable argument for its unconstitutionality, despite the fact that Black did not explain why he thought that, in the specific case, the African-American voters' rights to vote and not be discriminated against on the basis of race outweighed the party's right to self-determination.

\section{The Shopping Mall Cases}

The Shopping Mall Cases signify similar inconsistencies. Again, confronted with private actors encroaching upon other's individual rights and referring to state law to defend their actions, the Court started out examining the state law's as-applied constitutionality. Then, the Court abruptly switched to applying the public-function exception and asked if and under what conditions private actors become state actors. The first of these cases, Marsh v. Alabama (1946), ${ }^{69}$ dealt with a confrontation between a company town, Chickasaw, and a Jehovah's Witness, Grace Marsh, who tried to distribute religious leaflets on one of the town's sidewalks. Based on state trespass law, Marsh was asked to leave, and when she refused, she was arrested by a deputy sheriff and convicted of trespass by a state court. ${ }^{70}$

Writing for the Court, Justice Black broke sharply from the White Primary Cases' public-function exception and, instead of examining whether the private town was a state actor, focused on the case's obvious state action, the enforcement of the state's trespass law, and its as-applied constitutionality. ${ }^{71}$ Black wrote, "[W]e are asked to decide whether a State, consistently with the First and Fourteenth Amendments, can impose criminal punishment on a person who undertakes to distribute religious literature on the premises of a companyowned town contrary to the wishes of the town's management." 72 To answer this question, he developed the following rule to balance the company's right to property with Marsh's right to freedom of speech and religion: "Ownership does not always mean absolute dominion. The more an owner, for his advantage, opens up his property for use by the public in general, the more do his rights become circumscribed by the statutory and constitutional rights of those who use it." 73

It is only then that Black, briefly, talked about the private town's public function ("the town of Chickasaw does not function differently from any other town") $)^{74}$ and elaborated on some of the public-function exception's criteria (" $[t]$ he business block serves as the community shopping center, and is freely

69. Marsh v. Alabama, 326 U.S. 501, 503-04 (1946).

70. Id. at 503-04.

71. Id. at 502 .

72. Id.

73. Id. at 506 .

74. Id. at 508 . 
accessible and open to the people in the area"). ${ }^{75}$ However, Black did not conclude that this made the town a state actor. ${ }^{76}$ Instead, Black re-emphasized that the case's core question was the state trespass law's as-applied constitutionality. He answered that question by balancing the company's and Marsh's competing individual rights. Black wrote:

When we balance the Constitutional rights of owners of property against those of the people to enjoy freedom of press and religion, as we must here, we remain mindful of the fact that the latter occupy a preferred position. ... we must in all cases weigh the circumstances and ... appraise the ... reasons . . in support of the regulation ... of the rights. ... [T] he circumstance that the property rights to the premises where the deprivation of liberty ... took place, were held by others than the public, is not sufficient to justify the State's permitting a corporation to govern a community of citizens so as to restrict their fundamental liberties and the enforcement of such restraint by the application of a state statute. ${ }^{77}$

Justice Frankfurter, concurring, similarly focused on the enforcement of the trespass law and the balancing of competing constitutional principles. He argued that the freedom of speech and religion enjoys "a preferred position"

"[t]hese community aspects are decisive in adjusting the relations now before us, and more particularly in adjudicating the clash of freedoms which the Bill of Rights was designed to resolve -- the freedom of the community to regulate its life and the freedom of the individual to exercise his religion and to disseminate his ideas." 79

Even Justice Reed, dissenting, engaged in balancing when he argued that "[ $t]$ he rights of the owner, which the Constitution protects as well as the right of free speech, are not outweighed by the interests of the trespasser, even though he trespasses in behalf of religion or free speech," ${ }^{80}$ because "[a]ppellant ... was free to engage in such practices on the [nearby] public highways, without becoming a trespasser on the company's property." $" 81$

The next shopping mall case, Amalgamated Food Employees Union v. Logan Valley Plaza, Inc. (1968), ${ }^{82}$ sent a more mixed message. The Court started out examining the state trespass law's as-applied constitutionality by balancing competing individual rights but then displayed characteristics of the public-

75. Id. (internal quotation marks omitted).

76. For a different analysis, see generally Michael J. Phillips, The Inevitable Incoherence of Modern State Action Doctrine, 28 ST. LouIS U. L. J. 683, 692-93 (1984).

77. Marsh, 326 U.S. at 509 (internal citations and quotation marks omitted).

78. Id. at 510 (Frankfurter, J., concurring).

79. Id. at 510-11.

80. Id. at 516 (Reed, J., dissenting) (joined by Chief Justice Stone and Justice Burton).

81. Id. at 517 .

82. Amalgamated Food Employees Union v. Logan Valley Plaza, Inc., 391 U.S. 308 (1968). 
function exception. Based on Pennsylvania's trespass law, a state court enjoined a union from picketing a store inside a private shopping mall. ${ }^{83}$

Marshall, writing for the Court, started out emphasizing that at issue was the state trespass law's as-applied constitutionality: "We granted certiorari to consider petitioners' contentions that the decisions of the state courts enjoining their picketing as a trespass are violative of their rights under the First and Fourteenth Amendments." ${ }^{84}$ Marshall continued "[t]he case squarely presents . . . the question whether Pennsylvania's generally valid rules against trespass . . . can be applied in these circumstances to bar petitioners from the Weis and Logan premises." 85

To answer the question, Marshall balanced the right to property on the one hand with the right to freedom of speech on the other and explained the balancing rules as follows: "The more an owner, for his own advantage, opens up his property for use by the public in general, the more do his rights become circumscribed by the statutory and constitutional rights of those who use it." ${ }^{" 86}$ To justify the high weight accorded to the pickets' speech, he wrote that even though the pickets could exercise their right to speak on public property " 500 feet away from the Weis store" this would have made it very difficult for the Weis customers, the main addressees of the speech, to see the pickets' placards. ${ }^{87}$ Additionally, this isolated location would have placed the pickets "in some danger by being forced to walk along heavily traveled roads." ${ }^{\text {" }}$ "Marshall concluded that the trespass law's enforcement made the expression of the pickets' views practically impossible $;{ }^{89}$ therefore, the private shop owners' rights weighed less because "unlike a situation involving a person's home, no meaningful claim to protection of a right of privacy can be advanced by respondents here. ${ }^{90}$ Nor . . . can any significant claim to protection of the normal business operation of the property be raised." 1

However, other aspects of Marshall's opinion point in a different direction. Marshall refers to the public-function exception, which favors treating the private shopping mall like a state actor, when he writes that " $[\mathrm{t}]$ his Court has also held ... that, under some circumstances property that is privately owned may, at least for First Amendment purposes, be treated as though it were publicly held" ${ }^{\prime 2}$ and "[t]he similarities between the business block in Marsh and the shopping center

83. Id. at $309,313$.

84. Id. at 309 .

85. Id. at 315 .

86. Id. at 325 .

87. Id. at 322 .

88. Id.

89. Id. at 323 .

90. This is a point with which Justice Douglas agrees in his concurring opinion. Id at 325 , 326.

91. Id. at 324 .

92. Id. at 316 . 
in the present case are striking. ${ }^{93}$

These latter arguments were countered by Black, who writes "I can find very little resemblance between the shopping mall involved in this case and Chickasaw, Alabama." ${ }^{\circ 4}$ Black continued with a detailed list that distinguished Logan's shopping mall from Marsh's company town: "There are no homes, there is no sewage disposal plant, there is not even a post office ...."

Yet, Black addressed Marshall's balancing arguments. He wrote that the mall owners' private property rights should weigh much more since the picketing took place in the super market's pickup zone, an area of eminent importance for the supermarket's operation, because customers use the pickup zone to load groceries into their cars. ${ }^{96}$ Another reason for according more weight to the owner's property rights was that the mall owners invite the public onto their property for commercial purposes - not picketing. ${ }^{97}$

In Lloyd Corp. v. Tanner (1972) ${ }^{98}$ the Court confronted the same basic question: May the private owner of a shopping mall use state trespass laws to prevent speech in his mall? Based on Oregon trespass law, Lloyd Corp. prevented distribution of handbills inside its mall inviting people to a meeting for an antiVietnam-war organization. ${ }^{99}$ After the distributors had been asked to leave, they left and continued their handbilling on public sidewalks right outside the mall. ${ }^{100}$ A District Court held that Lloyd's behavior violated the First Amendment; the Court of Appeals for the Ninth Circuit affirmed. ${ }^{101}$

Despite Marsh's clear emphasis on examining the state law's as applied constitutionality by balancing the competing individual rights involved, Justice Powell, writing for the Court in Lloyd ${ }^{102}$ focused on Marsh's public-functionexception aspect. Without any specific reference, Powell wrote, "The Court [in Marsh] simply held that where private interests were substituting for and performing the customary functions of government, First Amendment freedoms could not be denied ....."103

The problem that Powell then ran into was Logan. Powell had to admit that Logan applied the public-function exception to a shopping mall that was exactly like the one in Lloyd. ${ }^{104}$ If, however, Logan's mall fulfilled a public function and

93. Id. at 317 .

94. Id. at 331 (Black, J., dissenting).

95. Id.

96. Id. at 327 .

97. Id. at 332-33. Justice White in his dissent agrees with this, see id. at 338.

98. Lloyd Corp. v. Tanner, 407 U.S. 551, 552 (1972).

99. Id. at $552,556$.

100. $I d$. at 556 .

101. Id. at 556-57.

102. Id. at 552-53 (joined by Chief Justice Burger and Justices White, Blackmun, and Rehnquist).

103. Id. at 562 (emphasis added).

104. Id. at 563-64; see also id. at 575-77 (Marshall, J., dissenting) (Marshall, in dissent, 
was bound by the First Amendment, why not the mall in Lloyd? Powell tried to solve the problem by limiting Logan and its mall's public function to "a context where the First Amendment activity was related to the shopping center's operations." ${ }^{105}$ He then concluded that the First Amendment did not bind the shopping mall in Lloyd because the speech in Lloyd, anti-war protest, was not related to the mall's operations. ${ }^{106}$ As a result, the content of the speech exercised in the shopping mall determined the mall's function, a rather unusual result that Powell did not explain any further.

Only later in his opinion ${ }^{107}$ did Powell address the central issue from all previous Shopping Mall Cases: the conflict between the mall owner's right to protection of property and the speakers' right to freedom of speech. After referring to the First, Fifth, and Fourteenth Amendments, Powell stated that "accommodations between the values protected by these three Amendments are sometimes necessary ..." 108 and that "the Fifth and Fourteenth Amendment rights of private property owners, as well as the First Amendment rights of all citizens, must be respected and protected." 109

It is as attempts to find such "accommodations" that Powell's arguments become more convincing and begin to resemble the Court's balancing arguments in Marsh and Logan. The fact that shopping malls invite the public mainly for commercial, not political purposes, speaks to weighing the owner's property rights favorably against the protesters' free speech rights. ${ }^{110}$ In Logan, though, the fact that the next available public space was a considerable distance from the mall, thus making it impossible for the pickets to effectively convey their message to customers, is an argument for favoring the pickets' free speech rights Conversely, the public sidewalks in Lloyd were right outside the mall, so that stepping outside did not impede the protesters in conveying their message. ${ }^{111}$

The Court's opinion would have further benefited from engaging with Justice Marshall's balancing arguments. Marshall, dissenting, argued, "We must remember that it is a balance that we are striking -- a balance between the freedom to speak ... and the freedom of a private property owner to control his property." 112 Marshall thought that, in the specific case, speech should outweigh property because Portland's citizens fulfilled their shopping needs at the Lloyd center, so that speech would not be able to reach these citizens if it were prohibited inside the mall. ${ }^{113}$ The owner's privacy interests, on the other hand, weighed less because he previously opened his property to speech by allowing

\footnotetext{
confirms this comparison of the shopping mall in Logan to the mall in the present case).

105. Id. at 562 .

106. Id. at 564 .

107. Id. at 567.

108. Id.

109. Id. at 570 .

110. Id. at 564-65.

111. Id. at 566-67.

112. Id. at 580 (Marshall, J., dissenting).

113. Id. at 580-81.
} 
presidential candidates to give speeches at the mall. ${ }^{114}$ Finally, freedom of speech conveys such an important individual right that the theoretical possibility of littering inside a mall is not important enough to prevent handbilling. ${ }^{115}$ Furthermore, "there is no evidence ... that speech directed to topics unrelated to the shopping center would be more likely to impair the motivation of customers to buy than speech directed to the uses to which the Center is put." 116

The Court's moment of truth came in Hudgens v. NLRB (1976) ${ }^{117}$, where the fact pattern resembled that of Logan's, with speech related to a shopping mall's operations. Union pickets picketed inside a private mall in front of a store belonging to a warehouse that the pickets were on strike against. ${ }^{118}$ The pickets left after the mall's manager asked them to leave and threatened with arrest for violating state trespass law. ${ }^{119}$ The union filed an unfair labor practice charge against Hudgens, the mall owner, while the NLR Board entered a cease and desist order against Hudgens that the Court of Appeals upheld. ${ }^{120}$

Even though the Court could have dealt with the case on purely statutory grounds, ${ }^{121}$ it again chose to take up the constitutional question of free speech rights in a private shopping mall. And again, the Court reduced Marsh, as well as Logan, to public-function-exception cases. ${ }^{122}$ It asserted that Logan concluded that " $[t]$ he shopping center ... is clearly the functional equivalent of the business district of Chickasaw involved in Marsh" and that it was "[u]pon the basis of this conclusion" that the Logan Court held the First and Fourteenth Amendments applicable. ${ }^{123}$

Based on these improper reductions of two cases, the Court then decided to overrule Logan. The Court argued that Logan was wrongly decided and that the First Amendment does not apply to private shopping malls because private shopping malls do not operate as a functional equivalent to a town. ${ }^{124}$ Simply ignoring the clear balancing language in all previous shopping mall cases, the Court argued that the necessary accommodation of the conflict between labor rights and private property rights presented a task for the NLR Board and reviewing courts under the National Labor Relations Act, hence why the Court remanded the case. ${ }^{125}$ Justice White, concurring, used the balancing language of the previous cases. He argued that Hudgens' property rights outweighed the

114. Id. at 578 .

115. Id. at 582 .

116. Id. at 581-82.

117. Hudgens v. NLRB, 424 U.S. 507, 508 (1976).

118. Id. at 509.

119. Id.

120. Id. at 509-12.

121. National Labor Relations Act $§ 7,29$ U.S.C. $§ 157$ (2019).

122. Hudgens, 424 U.S. at 513-14.

123. Id. at 516 .

124. Id. at 516-17, 520-21.

125. Id. at $521,523$. 
pickets' speech right because picketing this specific store proved unnecessary since the strike was directed at a warehouse not located inside the mall. ${ }^{126}$

Justice Marshall in dissent (joined by Brennan) paid the price for the fact that his language in Logan wavered between balancing and the public-function exception. Marshall recognized that Logan and Lloyd were irreconcilable as applications of the public-function exception. If the mall in Logan was the functional equivalent of the business district in Marsh, then the same had to be true for the mall in Lloyd because both malls were practically identical. If, because of the mall's public function, the First Amendment applied in Logan, it must equally apply in Lloyd. Under the public-function exception, it was inexplicable why picketing was allowed in Logan and handbilling was prohibited in Lloyd. ${ }^{127}$ Against this background, Marshall now tried to preserve Logan by focusing on balancing instead of the public-function exception. He limited Logan to cases in which "(1) the picketing is directly related in its purpose to the use to which the shopping center property is put, and (2) no other reasonable opportunities for the pickets to convey their message to the intended audience are available." $" 128$

This limitation seems impossible within the public-function exception. Whether or not a shopping mall fulfills a public function can hardly depend on the content of the speech exercised inside the mall. As part of a balancing test, however, it makes a lot of sense to argue that the speech right weighs relatively strongly if "the only reasonable opportunity for the pickets to convey their message" is to do it right in front of the store that is involved in the labor dispute. In Marsh and Logan, this was exactly why freedom of religion and speech outweighed property rights: because the closest available public spaces in which speech/religion could have been exercised were too dangerous or too far removed from the speech's listeners so that the speech's effectiveness would have been seriously undermined. Under pressure in Hudgens, Marshall elaborated this crucial point much more clearly than he did in Logan or Lloyd: "[T]he crucial fact in Marsh was that the company owned the traditional forums essential for effective communication; it was immaterial that the company also owned a sewer system and that its property in other respects resembled a town." "29 Similarly in Logan, Marshall explained the weight of speech as follows: "The roadways, parking lots, and walkways of the modern shopping center may be as essential for effective speech as the streets and sidewalks in the municipal or company-owned town." ${ }^{130}$ It is thus not the shopping center's "public function" that justifies the application of individual rights to private actors. Instead, the monopolization of forums essential for effective communication ${ }^{131}$ serves as a meaningful argument for weighing speech more strongly than property in a situation where speech and

126. Id. at 525 (White, J., concurring).

127. Id. at 535-36 (Marshall, J., dissenting).

128. Id. at 536 (internal quotation marks omitted).

129. Id. at 539 .

130. Id. at 539-40.

131. Id. 
property collide. The specific weight that is accorded to speech in a specific situation may depend, among other things, on the speech's content. ${ }^{132}$ For example, the Vietnam war may be effectively protested on public sidewalks right outside the mall, while that may not be the case for a labor dispute that involves a specific store inside the mall.

The decisive argument in these cases is not that the First Amendment always applies to private shopping malls when they are the "functional equivalent" of public towns and their business blocks or have assumed a "traditional [government] function." 133 Instead, the argument is that in a situation in which freedom of speech and the right to property collide, the former outweighs the latter if, in the specific case, there are no alternative locations available for effective speech while the private owner has already opened his property to the public. The Court evaded elaborating on these important balancing aspects by focusing on whether or not a private shopping mall fulfills a public function.

\section{The Judicial Enforcement Cases}

The Judicial Enforcement cases exemplify the so-called entanglement exception and its inconsistencies.

The facts of the first case, Corrigan v. Buckley, ${ }^{134}$ are almost identical with those of the later, famous, case of Shelley v. Kraemer (1948). Corrigan and Buckley were private homeowners on a street in Washington, D.C. who, together with other private property owners in the same neighborhood, had entered into a private covenant prohibiting the sale of property to African-Americans. After Corrigan, in violation of the covenant, had sold land to an African-American, Buckley sued Corrigan to enforce the covenant. ${ }^{135}$ The District Court granted the requested injunction and the Court of Appeals upheld.

The Court, unanimously, denied hearing the case because the claim that the restrictive covenant violated individual rights under the Fifth, Thirteenth, and Fourteenth Amendments was "entirely lacking in substance." "It is obvious that none of these amendments prohibited private individuals from entering into contracts respecting the control and disposition of their own property." ${ }^{136}$ That state law, as applied by the courts to these covenants, may be state action in violation of individual rights did not even occur to the Court. ${ }^{137}$

The Court's attitude changed dramatically in Shelley v. Kraemer (1948). ${ }^{138}$ Confronted with almost identical facts (Fitzgerald and Kraemer owned private property under a restrictive covenant that prohibited owners from selling property

132. Id. at 542 .

133. Id. at 543 .

134. Corrigan v. Buckley, 271 U.S. 323 (1926).

135. Id. at $323,327-28$.

136. Id. at 330 .

137. Id. at 331.

138. Shelley v. Kraemer, 334 U.S. 1 (1948). 
to African-Americans; Fitzgerald sold to Shelley, an African-American), the Court found racially discriminatory state action in the state court's enforcement of the covenant.

In stark contrast to Corrigan, the Shelley Court immediately turned to examining the constitutionality of the state court's enforcement of the covenant and stated that "we are called upon to consider whether enforcement by state courts of the restrictive agreements in these cases may be deemed to be the acts of those States, and, if so, whether that action has denied these petitioners the equal protection of the laws." 139 The Court continued that "[w]e have no doubt that there has been state action in these cases." 140 The Court explained that it was only because of the state court's active intervention that the transfer of property between Fitzgerald and Shelley was prevented and that this was a case in which "the States have made available . . the full coercive power of government to deny to petitioners, on the grounds of race ...., the enjoyment of property rights ...."141

Regarding the problem that the state court only enforced facially race-neutral state common law according to which private agreements had to be enforced while the race-based discrimination was embedded in the private covenant, the Court argued that the Fourteenth Amendment is not "ineffective simply because the particular pattern of discrimination, which the State has enforced, was defined initially by the terms of a private agreement." ${ }^{142}$ After reemphasizing that court action is state action, the Court stated that "when the effect of that action is to deny rights subject to the protection of the Fourteenth Amendment, it is the obligation of this Court to enforce the constitutional commands."143

Examining whether the state action violated the Fourteenth Amendment, the Court engaged in what looks like balancing the parties' competing individual rights. Freedom from discrimination in the enjoyment of property rights weighed particularly heavily because it was among "the basic objectives sought to be effectuated by the framers of the Fourteenth Amendment." ${ }^{144}$ Public interest was not able to outweigh the importance of non-discrimination: "Nor may the discriminations . . . be justified as proper exertions of state police power."145 Neither could Shelley's right to non-discrimination be outweighed by Kraemer's rights to protection of property and freedom of contract: "The Constitution confers upon no individual the right to demand action by the State which results in the denial of equal protection of the laws to other individuals." ${ }^{146}$ As a result, the right to non-discrimination outweighed all other constitutional aspects:

139. Id. at 18 .

140. Id. at 19 .

141. Id.

142. Id. at 20 .

143. Id.

144. Id.

145. Id at 21 .

146. Id. at 22 . 
Whatever else the framers sought to achieve, it is clear that the matter of primary concern was the establishment of equality in the enjoyment of basic civil and political rights and the preservation of those rights from discriminatory action on the part of the State based on considerations of race or color. ${ }^{147}$

After ignoring the obvious state action in Corrigan, the Shelley Court did not hesitate to consider the enforcement of facially race-neutral state law state action and examine its as-applied constitutionality by balancing competing individual rights (protection of property, freedom of contract, non-discrimination) and other constitutional principles, such as the state's police power.

Similarly, in Barrows v. Jackson, ${ }^{148}$ the Court immediately identified the state court's enforcement of a racially restrictive private covenant as the relevant state action and focused on examining its constitutionality. The state court had enforced the covenant by imposing damages upon the party who had violated the covenant by permitting "non-Caucasians" to move into the premises. ${ }^{149}$ As regards to the relevant state action, the Court argued: "The action of a state court at law to sanction the validity of the restrictive covenant here involved would constitute state action as surely as it was state action to enforce such covenants in equity, as in Shelley." " As regards to the state action's constitutionality, the Court argued that because the state court's award of damages will reduce the chances of "non-Caucasians" to buy property solely because of their race, they will be deprived of their equal right to buy property. ${ }^{151}$

Chief Justice Vinson, who had written for the Court in Shelley, dissented because he disagreed with the Court's balancing result. Balancing the right to equal protection with the right to freedom of contract, Vinson argued that, in this case, the right to freedom of contract outweighed the right to equal protection because, on the one hand, the African-American buyer's rights had not been infringed because the contract and the transfer of property remained unimpaired. On the other hand, the property's seller deserved no protection because he voluntarily signed the restrictive covenant and, probably, benefited from it. The remaining indirect impact on the opportunities of potential future colored buyers, according to Vinson, was too vague to change the outcome. ${ }^{152}$

The Court argued similarly in New York Times v. Sullivan. ${ }^{153}$ It did not

147. Id. at 23 .

148. Barrows v. Jackson, 346 U.S. 249 (1953).

149. Id. at 252 .

150. Id. at 254 .

151. Id. The Court problematized the property seller's standing because his right to equal protection was not affected and his African-American buyer did not sue because the damages were not imposed on him. See id. In fact, the actual buyer's rights were not affected at all by the verdict because the validity of the sale of the property was not questioned. See id. at 268.

152. Id. at 262, 267-68.

153. New York Times Co. v. Sullivan, 376 U.S. 254 (1964). 
hesitate to acknowledge that a state court's application of state common libel law to a relationship between private actors was state action. The Court also admitted that its main task was to examine the state action's constitutionality, namely whether the state court's enforcement of Alabama's libel law against the New York Times violated the Times' freedom of speech and the press under the First and Fourteenth Amendments. ${ }^{154}$ The Court emphasized that what is relevant under the state action doctrine "is not the form in which state power has been applied but, whatever the form, whether such power has, in fact, been exercised." 155

The Court then proceeded to balance the Times' freedom of speech and the press with Sullivan's right to protection of his reputation. ${ }^{156}$ For example, the Court argued that "libel can claim no talismanic immunity from constitutional limitations" but "must be measured by standards that satisfy the First Amendment." 157 Developing balancing rules, the Court emphasized the First Amendment's strong weight because it is "a fundamental principle of our constitutional system" and there is "a profound national commitment to the principle that debate on public issues should be uninhibited, robust, and wideopen." ${ }^{158}$ On the other hand, the Court considered whether the Time's statement "forfeits that protection by the falsity of some of its factual statements and by its alleged defamation of respondent," 159 by the "concern for the dignity and reputation" of Sullivan, ${ }^{160}$ or by the combination of both. ${ }^{161}$ The principle of federalism was also taken into account, as was the chilling effect on speech of an imposition of civil damages. ${ }^{162}$ After balancing these competing principles, the Court concluded that the award of damages for libel is only justified upon a proof of "actual malice," 163 which was not delivered here with "the convincing clarity which the constitutional standard demands."164

It was in Evans v. Abney ${ }^{165}$ that the Court suddenly changed its approach and seemed to go back to Corrigan. A court in Georgia had decided that, based on state law, land that had been willed to a trust for the operation of a public park "for whites only" had to be returned to the heirs of the deceased when it turned out that it was no longer legally possible to run public parks on a racially segregated basis. The state court had interpreted the private will as saying that the land must be returned when it could not be used for racially discriminatory

154. Id. at $265,268$.

155. Id. at 265 .

156. Id. at 269 .

157. Id.

158. Id. at 269-70.

159. Id. at 271.

160. Id. at $272-73$.

161. Id. at $273-74$.

162. Id. at 277.

163. $I d$. at 283 .

164. Id. at 285-86.

165. Evans v. Abney, 396 U.S. 435 (1970). 
purposes and had enforced the will. ${ }^{166}$

Justice Black, writing for the Court, did not deny that the state court's enforcement of the racially discriminatory will was state action. Still, he found no violation of the Equal Protection Clause. Instead of emphasizing that the effect of the court's action was to deny rights protected by the Fourteenth Amendment, Black argued that there was "not the slightest indication that any of the Georgia judges involved were motivated by racial animus or discriminatory intent."167 Racial restrictions, according to Black, were "solely the product of the testator's own full-blown social philosophy." 68

Compared with Shelley, Abney presents important changes in the Court's approach. First, discriminatory intent, or the lack of it, played no role in Shelley. For the Shelley Court it was decisive that the state action's effect was to deny rights protected by the Fourteenth Amendment. The same holds true for Barrows. ${ }^{169}$ In Abney, the Court focused on the state judges' intent. Second, the Abney Court ignored that, without the state court's intervention, the testator's racism could not have been enforced. In fact, the Abney Court mentioned the state action's effect and Shelley only in an afterthought, writing "the situation presented in this case is ... easily distinguishable from that presented in Shelley ... Here the effect of the Georgia decision eliminated all discrimination against Negroes in the park by eliminating the park itself, ... a loss shared equally by the white and Negro citizens ...." ${ }^{170}$ This statement, however, contradicts one of the core messages of Brown v. Board of Education. ${ }^{171}$ Even if the state court's decision would have deprived African-American and white citizens equally of a right of access to a public park, the social message emanating from such a decision clearly imposed a badge of inferiority upon African-Americans because it is obvious that the court lent state support to a private actor's racism. Only Justice Brennan considered this point in dissent, when he wrote that the court's return of the land to the heirs was state action that "conveys an unambiguous message of community involvement in racial discrimination." ${ }^{172}$ Moreover, one may argue that the state court's enforcement of the restrictive covenant in Shelley also equally deprived the African-American Shelley of the right to acquire property and the white Fitzgerald of the right to sell it.

A different reason for the Court's opinion shines through when Justice Black writes "the loss of charitable trusts such as Baconsfield is part of the price we pay for permitting deceased persons to exercise a continuing control over assets

166. Id. at $442-43$.

167. Id. at 445 .

168. Id. at 445 .

169. For a similar contradiction between Brown v. Board of Education (1954) and Washington v. Davis (1976), see Louis Seidman \& Mark Tushnet, Remnants of Belief: Contemporary Constitutional Issues 105 (1st ed. 1996).

170. Evans, 396 U.S. at 445.

171. Brown v. Bd. of Educ. of Topeka, 347 U.S. 483 (1954).

172. Evans, 396 U.S. at 453-54. 
owned by them at death." ${ }^{173}$ This statement implies that, under the circumstances of the particular case, the Court thought that the freedom of testation outweighed the right to non-discrimination or the public's right of access to a public park, a balancing consideration that would not only have been more in line with the previous decisions but would also have made the Court's considerations more transparent.

\section{CRITIQUE}

The Court's application of the state action doctrine has been almost unanimously criticized. Charles Black, for example, called it "a conceptual disaster area"; ${ }^{174}$ Erwin Chemerinsky, Stephen Gardbaum, and Mark Tushnet consider the entire doctrine unnecessary. ${ }^{175}$ Cass Sunstein emphasizes that all law, including law applied in private relationships, is state action that must comply with individual rights. ${ }^{176}$ The Court itself admits that its applications of the public-function and entanglement exceptions "have not been a model of consistency." 177

The critique may be categorized into an internal and an external critique. ${ }^{178}$ The internal critique attacks the inconsistencies of the Court's application of the doctrine and tries to develop criteria that allow for a more consistent determination of when a private actor must be deemed a state actor. The external critique, on the other hand, aims at "transcending" the state action doctrine and argues that the challenge is not to decide whether or not there is state action but whether or not obvious state action is constitutional. ${ }^{179}$

The internal critique runs into the same problems as the Court. Regardless of what criteria it develops, it eventually reaches a point where a "sifting of the facts" leads to more or less arbitrary decisions of whether or not the private actor, under the specific circumstances of the case, must be deemed a state actor.

It would be similarly wrong to abolish the state action doctrine. The critics are right in that the main problem is not to find state action but to determine its constitutionality. That, however, is a core challenge of applying the state action doctrine, not of "transcending" it. What is needed is a set of doctrinal tools that help courts determine the relevant state action in private relationships and

173. Id. at 447 .

174. Charles L. Black, “State Action," Equal Protection, and California's Proposition 14, 81 HARV. L. REV. 69, 95 (1967).

175. Stephen Gardbaum, The "Horizontal Effect" of Constitutional Rights, 102 MicH. L. REV. 387, 414-15, 418 (2003); see MARK Tushnet, State Action in 2020, in The Constitution in 2020 69-77 (Jack Balkin \& Reva Siegel eds., 1st ed. 2009); see Erwin Chemerinsky, Rethinking State Action, 80 Nw. L. ReV. 503, 522 (1985).

176. Cass Sunstein, The Partial Constitution 159-60 (1993); see Horowitz, supra note 6 , at 208 .

177. Edmonson v. Leesville Concrete Co., 500 U.S. 614, 632 (1991).

178. See Gardbaum, supra note 175 , at 412.

179. Id. at 414-15; Horowitz, supra note 6, at 208-09. 
examine its as-applied constitutionality. So far, external critics have not provided such tools.

Chemerinsky, for example, wants to abolish the state action doctrine and directly apply individual rights to all actors, government as well as private. This, according to Chemerinsky, would not mean that private actors and the government would be equally bound by individual rights because, unlike the government, private actors would not only be bound but also be protected by individual rights. It would mean, though, that courts could not dismiss cases for lack of state action. They would have to decide all cases based on the merits, balancing the competing constitutional principles involved in each case. ${ }^{180}$ Still, Chemerinsky leaves us with a problem, he explains neither how exactly to determine relevant state action nor how to balance competing constitutional principles. Yet the details, particularly of balancing competing constitutional principles, are among the greatest concerns of this proposal's critics. Generally, critics are very skeptical of the Court engaging in balancing because they think balancing is inherently unprincipled and implies political choices which are the legislature's, not the judiciary's task. ${ }^{181}$

Tushnet's proposal poses a similar problem. He agrees with Chemerinsky in that the state action doctrine obfuscates the truly relevant questions and should be abolished. ${ }^{182}$ The truly relevant question, according to Tushnet, is what constitutional duties governments have. ${ }^{183}$ Like Chemerinsky, Tushnet does not tell us exactly how to answer that question. He only tells us that it is a question of substantive constitutional law. ${ }^{184}$

Gardbaum, like Chemerinsky and Tushnet, wants to abolish the state action doctrine, and decide cases on their merits by balancing competing individual rights. Gardbaum does not propose a direct application of individual rights to private actors, but wants to apply individual rights to all law, including law that is being applied in private relationships. ${ }^{185}$ Based on Article VI's Supremacy Clause, he argues, the Constitution sets the standard for every law, including law that is being applied in private relationships.

My first critique of Gardbaum's proposal is that it does not really abolish the state action doctrine. Law applied in private relationships is state action and, as long as Gardbaum is unwilling to apply the constitution directly to private

180. Chemerinsky, supra note 175 , at $506,527,539,550$.

181. Jacco Bomhoff, Lüth's 50th Anniversary: Some Comparative Observations on the German Foundations of Judicial Balancing, 9 GER. L. J. 121-22 (2008); Louis Henkin, Infallibility Under Law: Constitutional Balancing, 78 Colum. L. Rev. 1022, 1048 (1978).

182. TushneT, supra note 175 , at 74,77 .

183. Id. at $69,74,77$.

184. Id. at 72,75 .

185. Gardbaum, supra note 175, at 430 (arguing with respect to Marsh v. Alabama, that the question should not have been whether or not the company town that prevented Marsh from distributing leaflets was a state actor but whether the state trespass law as applied against Marsh was constitutional). See also Chemerinsky, supra note 175, at 506, 527, 539, 550. 
individuals, he does not abolish the state action requirement. My second critique is that Gardbaum's proposal is contradictory. One the one hand, it wants to abolish the state action requirement, on the other hand it re-introduces that very requirement by making the level of protection an individual right affords depend on the legislature's intent. ${ }^{186} \mathrm{He}$ wants to apply strict scrutiny only to laws that show discriminatory legislative intent. A specific legislative intent, however, is a state action requirement. What's more, is that Gardbaum's proposal is unable to solve the problems of the cases that I analyzed above. For example, he would have to let the Jaybirds get away with depriving African-Americans of their voting rights because there was no racially discriminatory legislative intent visible in the laws. The same holds true for facially neutral trespass or contract laws that private mall or homeowners used to interfere with other people's speech or to engage in private racism. For lack of unconstitutional legislative intent, Gardbaum would have to apply the rationality test in these cases and conclude that individual rights were not violated.

Another look at Shelley will clarify this point. The problem in Shelley was not the state actors' intent or the extent to which state actors were responsible for private race-based discrimination. Neither the state legislature nor the state court had discriminatory intent in Shelley. The legislature had adopted a facially raceneutral law according to which private agreements must be enforced; the court had enforced this law. Both, state actors and private actors were responsible for the discrimination. State actors provided the law and its enforcement. Private actors engaged in the discrimination and used the available legal means to enforce it. It was not only because of the court's enforcement of the restrictive covenant that Shelley could not acquire the property. It was equally because private homeowners had signed the covenant and Kraemer had brought the lawsuit to enforce it.

The problem in Shelley, like in other state action cases, was to determine which of the individual rights that were affected by the obvious state action - the law regulating the private relationship and this law's enforcement - should prevail under the circumstances of the specific case. When the legislature grants a right to enforce private covenants and the court enforces it, both state actors protect Kraemer's freedom of contract at the expense of Shelley's rights to nondiscrimination and property. ${ }^{187}$ The decisive question is: Is that constitutional, or, more precisely, does, under the specific circumstances of the case, the struck balance remain within the limits set by the Constitution? ${ }^{188}$

This is the question that Herbert Wechsler and, more recently, Richard Epstein addressed. ${ }^{189}$ They complained that the Court's decision in Shelley was

186. Gardbaum, supra note 175 , at 439.

187. See, e.g., Henkin, supra note 181.

188. See, e.g., Chemerinsky, supra note 175, at 540; Robert Glennon \& John Nowak, $A$ Functional Analysis of the Fourteenth Amendment "State Action" Requirement, 1976 SUP. CT. REV. 221, 230-31.

189. Herbert Wechsler, Toward Neutral Principles of Constitutional Law, 73 HARV. L. REV. 1 (1959); Richard Epstein, Classical Liberalism Meets the New Constitutional Order: A Comment 
not sufficiently principled. This is because the Court did not take into account that not enforcing the racially restrictive covenant would deny Kraemer's rights to property and equal protection since the covenant was valid in all other respects. ${ }^{190}$ According to this view, a court's enforcement of a private covenant is state action that violates neither the Due Process nor the Equal Protection Clause "when it makes no independent decision but only enforces private rights on request."191 Epstein argues that denying courts the authority to enforce racially restrictive covenants is presumptively a taking of private property without just compensation. ${ }^{192}$ Wechsler asks "why is the enforcement of the private covenant a state discrimination rather than a legal recognition of the freedom of the individual?"'193

These are good points, but, despite asking the right questions, Wechsler and Epstein repeat Gardbaum's mistake by not taking all implicated rights into account. While considering Kraemer's rights to property and freedom of contract, they ignore Shelley's right to non-discrimination and property. The state court's enforcement of the racially restrictive covenant interfered with Shelley's rights by taking away his property. ${ }^{194}$ These rights must be considered just like Kraemer's rights to freedom of contract and protection of property. If Wechsler and Epstein blame the Court for overlooking Kraemer's rights, Wechsler and Epstein are to be blamed for overlooking Shelley's. ${ }^{195}$ The decisive question that none of the authors answers is how exactly to strike the right balance between these competing individual rights and other constitutional principles in a principled way. ${ }^{196}$

My thesis is that the German concepts of horizontalism and proportionality can provide the doctrinal tools for a more principled application of the US state action doctrine. In what follows I will first introduce these two concepts in order to then show how they can improve the doctrine's application.

\section{THE GERMAN CONCEPTS OF HORIZONTALISM AND PROPORTIONALITY}

The German Federal Constitutional Court (Bundesverfassungsgericht, BVerfG) introduced the concepts of horizontalism (Drittwirkung) and

on Mark Tushnet, 3 CHI. J. OF INT'L L. 455 (2002).

190. Wechsler, supra note 189, at 29.

191. Epstein, supra note 189 , at 460.

192. Id. at 460-61.

193. Wechsler, supra note 189 , at 29.

194. Epstein, supra note 189, at 461 (the right to non-discrimination is not merely a public policy consideration, as Epstein implies; it is an individual right that the state court's enforcement of the restrictive private covenant interferes with).

195. Louis Pollak, Racial Discrimination and Judicial Integrity: A Reply to Professor Wechsler, 108 U. PA. L. REV. 1, 9 (1959).

196. See Henkin, supra note 181, at 1043; This is true for Sunstein's and Horowitz's proposals as well. 
proportionality (Verhältnismäßigkeit) to German constitutional law with the socalled Lüth decision of 15 January $1958 .{ }^{197}$ The decision must be viewed against the historical background of the Constitution of the Weimar Republic, which had been silent on the question of substantive, as opposed to procedural, judicial review of federal laws. ${ }^{198}$ A lively debate on the topic as well as the Reichsgericht's attempt in 1929 to establish substantive judicial review by, for the first time, holding a federal statute unconstitutional had been cut short by Hitler's ascent to power on 30 January $1933 .{ }^{199}$ The Nazi regime had practically abolished constitutional law and replaced it with the 'Führer principle' according to which law was created by a 'Führer order' ${ }^{200}$ Responding to this history, one of the main tasks of the West German Basic Law of 1949 (Grundgesetz, GG), was to provide the new Federal Republic of Germany with a constitutional order that established democracy combined with effective individual rights protection. The core means to achieve these goals was, besides a democratic structure of government, a detailed list of individual rights that were explicitly binding on the legislature, the executive, and the judiciary. ${ }^{201}$ This was combined with a comprehensive system of judicial review of legislative, executive, and judicial acts. Another measure was to establish the BVerfG, a court specializing in constitutional law. Doctrinally, Lüth was decided against a background that, based on $19^{\text {th }}$ century liberalism, sharply distinguished between private and public law. The German Civil Code (Bürgerliches Gesetzbuch, BGB) was considered the paradigm private law that regulated private relationships to which the state had no access, except where the judiciary was needed to enforce private rights. ${ }^{202}$ At the same time, in the light of Germany's historical experience with Nazi totalitarianism, protecting the individual right to freedom of expression was of preeminent importance for the Federal Republic's young democracy. ${ }^{203}$ It was this tension between a sharp distinction between the public and the private sphere on the one hand, and effective individual rights protection on the other; that brought the Court to introducing the concepts of horizontalism and proportionality to German constitutional law.

\section{A. Horizontalism}

The concept of horizontalism, or third-party effect, treats the law that is being

197. BVerfG, 1 BvR 400/51, Jan. 15, 1958; Konrad Hesse, Principles of Constitutional LAW of THe Federal Republic of Germany 14 (20th ed. 1999).

198. J.J. Lenoir, Judicial Review in Germany Under the Weimar Constitution, 14 TuL. L. Rev. 361, 365-66 (1939-1940).

199. Id. at 370; Gerhard Casper, Guardians of the Constitution, 53 S. CAL. L. REV. 773, 778 (1980).

200. Id.

201. Peter Quint, The Imperfect Union: Constitutional Structures of German UNIFICATION, 248 (2003) (ebook).

202. Id. at 255.

203. BVerG, Jan 15, 1948BvR 400/51 ๆ 33. 
applied between private parties as state action that must comply with the constitution. It thus applies constitutional law in private relationships, not directly to the private parties' behavior; but to the law that is being applied to the behavior of private parties. The Court examines this law's constitutionality under the specific circumstances of the specific case, i.e. its as-applied constitutionality.

Erich Lüth, in his role as a private citizen, had publicly called for a boycott of Veit Harlan's movie, Immortal Beloved. Harlan was well known at the time for the role he had played in Nazi Germany, where he had directed a viciously antisemitic Nazi propaganda movie, Jud Süß. Immortal Beloved was Harlan's first movie in post-WWII Germany. Lüth, who was working for the reconciliation between Christians and Jews after the Holocaust, aimed at publicly reminding people of the role Harlan had played in Nazi Germany. Based on paragraph 826 of the German Civil Code, a Hamburg civil court enjoined Lüth from repeating his call for a boycott. The Court argued that Lüth had intentionally harmed the movie's distributors in a manner "offensive to good morals." Lüth argued that this verdict violated his right to free expression under Art. 5 (I) of the German Constitution, the Basic Law (Grundgesetz, GG). The film distributors countered saying their relationship with Lüth was one between private individuals, and only the German Civil Code, not the constitution, applied. The BVerfG thus had to decide if and under what circumstances constitutional rights applied in private relationships, a question that German constitutional scholarship refers to as the "horizontal" or "third-party" effect of constitutional rights. ${ }^{204}$ The BVerfG argued that it was not necessary to decide if constitutional rights can only bind state actors or if - at least the most important - constitutional rights may also bind private actors. ${ }^{205}$ Instead, the Court emphasized that constitutional rights are not only defense rights of an individual against the government, but also "elements of an objective hierarchy of values" (Elemente einer objektiven Wertordnung). All law, including private law, must comply with this value order and must be interpreted in this light. ${ }^{206}$ In particular, abstract legal terms that must be interpreted when applied to the facts of a case must be interpreted and applied in the light of constitutional rights. ${ }^{207}$ The BVerfG is limited to examining whether lower courts made mistakes in observing the impact of constitutional rights on ordinary law; it cannot correct other, non-constitutional, mistakes in the interpretation or application of ordinary law. ${ }^{208}$ Accordingly, constitutional rights have an "indirect" effect on private legal relationships. ${ }^{209}$

204. Hesse, supra note 197, at 351; Thorsten Kingreen AND RALF Poscher, Fundamental Rights, StaAtsrecht II 189 (32 ed. 2016); Robert Alexy, Theorie Der GRUNDRECHTE, 475 (1985).

205. BVerG, Jan 15, 1948 BvR 400/51 ๆ 24.

206. BVerG, Jan 15, 1948 BvR 400/51 ๆ 27.

207. BVerG, Jan 15, 1948 BvR 400/51 ๆ 29.

208. BVerG, Jan 15, 1948 BvR 400/51 930.

209. BVerG, Jan 15, 1948 BvR 400/51 ๆ 29. 


\section{B. Proportionality}

The Lüth decision's other major contribution was based on the BVerfG's finding that substantively the case was not only about Lüth's freedom of speech, (Art. $5 \mathrm{GG}$ ) but also about Harlan's (and the film distributors') right to engage in commercial activities; a right protected by paragraph 826 of the German Civil Code. ${ }^{210}$ The Court argued that there is a "reciprocal effect" (Wechselwirkung) between the constitutional right that is being limited (freedom of speech) and the limiting law (para. 826 BGB). ${ }^{211}$ That means that the law that is limiting Lüth's constitutional right must itself be interpreted in the light of the constitutional right that is being limited. A balance must be struck between the competing rights. In the specific case, the Court came out on Lüth's side because Lüth did not act out of egoistic motives and there was an overwhelming public interest in promoting the cause of Christian-Jewish reconciliation at the time. ${ }^{212}$

The Court, supported by constitutional scholarship, further developed the idea of balancing into what came to be known as the proportionality test. The proportionality test is based on the idea that constitutional and other rights start out as principles. Principles are "commands to optimize," i.e. commands to realize the protected principle to the highest degree possible under the actual and legal circumstances of the specific case. ${ }^{213}$ In Lüth, for example, the Court did not decide separately whether Lüth's call for a boycott was protected by his freedom of speech or if Harlan's movie was protected by his right to property. Instead, the Court recognized that the enforcement of property protection by the Hamburg court had an impact on both, Lüth's freedom of speech and Harlan's right to property. Both rights must be realized as optimally as possible under the circumstances of the specific case, i.e. under the conditions of what was actually and legally possible.

According to Alexy, the character of rights as principles pre-determines a specific procedure for how to decide the constitutionality of a state act that interferes with a right. ${ }^{214}$ In order to be constitutional, an interfering state act must comply with the principle's inherent command to optimize. That means that the state act can only be constitutional if it is (i) suitable to promote the purpose that it purports to promote; (ii) necessary to promote that purpose; and (iii) proportional in the narrower sense, i.e. under the circumstances of the specific case it must be justified to promote that purpose at the expense of the principle that the state act interferes with. It is obvious that a state act that interferes with an individual right, and is not even suitable to promote the purpose that it shall

210. BVerG, Jan 15, 1948 BvR 400/51 ๆ 39.

211. BVerG, Jan 15, 1948 BvR 400/51 ๆ 32.

212. BVerG, Jan 15,1948 BvR 400/51 ๆ 50.

213. AleXy, Theorie, supra note 204, at 71, 75, 76; Robert Alexy, Rights, Legal Reasoning and Rational Discourse, RATIO JuRis Vol. 5, No. 2, July 1992, at 143,152, 149.

214. Similarly, Henkin writes about balancing "The task and the process inhere in constitutional government and cannot be avoided," Louis Henkin, Shelley v Kraemer: Notes for a Revised Opinion, 110 UnIV. Of PenN. L. ReV. 473, 493 (1962). 
promote, cannot be in compliance with the command to optimize the individual right that it interferes with. ${ }^{215}$ The same holds true for a state act that is not necessary to promote its intended purpose, because in that case there are other, less invasive, i.e. more optimizing, means to achieve the same purpose. ${ }^{216}$ The third requirement, proportionality in the narrower sense, is a necessary consequence of the command to optimize, as well. Since all competing rights need to be optimized to the extent possible under the circumstances of the specific case, one right may only be limited to the extent that this can be justified by the optimization of the competing right. Rights as principles demand Paretooptimality. ${ }^{217}$

The three requirements that constitute the proportionality test are, thus, no scholarly invention but a requirement imposed by the principles-character of rights. ${ }^{218}$ While suitability and necessity were the actual limitations, freedom of speech was the legal limitation that the Constitution imposed on the state's authority to protect property in the Lüth case. ${ }^{219}$ It is in this final balancing process, that the acting state as well as the reviewing Court must explain why, under the circumstances of the specific case, it is justified to protect Lüth's freedom of speech at the expense of Harlan's property. Since property and speech/religion are in conflict with each other in the specific case, they represent the legal limitations that the Constitution has imposed on the optimization of each. According to the rights' character as principles, the conflict is resolved neither by declaring one of the principles invalid or inapplicable nor by adding a general exception to one of the principles. ${ }^{220}$ It is resolved by establishing a specific relationship, a "balance," between the competing principles under the specific circumstances of the case. The Court must explain the conditions under which one right outweighs another and give reasons for its conclusion. ${ }^{221}$ The Court uses the metaphor of "weighing" or "balancing" to express this process of determining the conditions under which one right prevails over another and of giving reasons for this determination. ${ }^{222}$ By determining the conditions under which one right outweighs the other in the specific case, the Court formulates a rule for the relationship between the competing rights under the specific circumstances. ${ }^{223}$ This rule may apply in similar cases in the future. The Court formulates the rule not intuitively, but as a result of a rational process, because the Court gives reasons for formulating the rules the way it does. ${ }^{224}$ These reasons

215. Alexy, Rights, supra note 213, at 149.

216. See AleXy, TheOrIE, supra note 204, at 101; Alexy, Rights, supra note 213, at 149.

217. Id.

218. See AleXy, TheORIE, supra note 204, at 100; Alexy, Rights, supra note 213, at 149.

219. See AleXY, Theorie, supra note 204, at 100.

220. See id. at 81.

221. Henkin, supra note 181, at 1045-49.

222. See Alexy, Theorie, supra note 204, at 50-54.

223. Id. at 100 .

224. See id. at 381-87; Alexy, Rights, supra note 213, at 149. 
are derived from the general canons of constitutional interpretation (textual, contextual, systematic, historical, teleological, precedent, etc. $)^{225}$ and ensure that the proportionality test is a rational process.

Admittedly, the proportionality test only prescribes the direction of the argument, not its result, which still depends on the judge's opinion of the importance of the respective individual rights in the specific case. ${ }^{226}$ Still, the proportionality test provides a rational structure of reasoning by forcing the Court to openly state and account for the reasons it applies in its decisions. ${ }^{227}$ This is a profound advantage compared with the US Supreme Court's application of exceptions to the state action doctrine. Applying the doctrine, in combination with horizontalism and the proportionality test, would no longer allow the Court to arbitrarily exempt state law from judicial review and hide its true reasons behind obscure formulas and fact-sifting. ${ }^{228}$ The Court would arrive at rational solutions through determining prima facie preferences for specific principles (such as freedom of speech) and, over time, through establishing a network of more specific preferences. ${ }^{229}$ These rules, again, over time, would combine to form a principled doctrine of state action and individual rights. Principled decision-making does not require abolishing value judgments, but it does require making necessary value judgments in a transparent and predictable way. ${ }^{230}$

\section{APPLYING HORIZONTALISM AND PROPORTIONALITY TO US STATE ACTION CASES}

If the concepts of horizontalism and proportionality would be applied to US state action cases, we would see two things: (1) The US Supreme Court, or at least some of its justices, already did apply these concepts in many cases, yet, without properly theorizing the approach; and (2) applying the concepts consistently and openly in all cases would lead to a more principled application of the US state action doctrine.

\section{A. The US Supreme Court's Own Practice}

The above case analysis demonstrates that the Court, or at least some of its justices, already applied horizontalism and the proportionality test, starting as early as the Civil Rights Cases, where the Court established the state action doctrine and gave it a simple structure: (1) Determine the relevant state action; and (2) Examine the state action's constitutionality. In later cases, the Court applied horizontalism by identifying as state action a law applied to the relationship between private actors. It applied the proportionality test by

225. See AleXy, Theorie, supra note 204, at 381-87.

226. Alexy, Rights, supra note 213, at 150.

227. Id.

228. The lack of transparency is also criticized by Tushnet. See TusHnET, supra note 1, at 219.

229. AleXy, TheOrie, supra note 204, at 142, 143, 153; This is also what, for example, Henkin has demanded. See Henkin, supra note 181, at 1049.

230. Friedrich Müller, Juristische MethodiK, Band I, 275, 382 (2013). 

AND PROPORTIONALITY

examining the law's as-applied constitutionality by balancing competing individual rights and other constitutional principles impacted by the state action and developing rules for the balancing. ${ }^{231}$

For example, in Marsh the Court applied horizontalism by identifying the enforcement of state trespass law against Marsh as the relevant state action and the proportionality test by examining the trespass law's as-applied constitutionality by weighing Marsh's freedoms of speech and religion against the private company's right to protection of property. ${ }^{232}$ Justice Marshall did the same in the other shopping mall cases, Logan, Lloyd, and Hudgens, examining trespass laws' as-applied constitutionality by balancing property rights with freedom of speech.

In Shelley, Barrows, and New York Times v. Sullivan, the Court applied horizontalism by identifying as the relevant state action a court's application of state common law and the proportionality test by examining the state action's constitutionality by balancing the involved competing individual rights, constitutional principles, and other legally protected interests. ${ }^{233}$

Balancing, as practiced in these cases, means developing criteria and shaping rules that determine the relationship between competing constitutional principles under specific circumstances. These rules help to determine what specific activities an individual right protects in a particular situation; they may be applied in future cases to further rationalize the balancing process. ${ }^{234}$

Some of the rules are very general. For example, with respect to the relationship between the right to property and the rights to freedom of speech and freedom of religion, the Court stated that "the latter occupy a preferred position" because they lie "at the foundation of free government by free men." ${ }^{235}$ A right's importance thus determines its weight in the balancing process.

Yet, most rules are more specific and more specifically shaped by the circumstances of the case. In Marsh, the Court stated: "[W]e must in all cases 'weigh the circumstances and appraise the reasons in support of the regulation of the rights." ${ }^{236}$ For example, Justice Marshall, in his Lloyd dissent, argued that freedom of speech is such an important right that the theoretical possibility of littering inside the mall is not important enough to prevent handbilling inside the mall, and "there is no evidence . . . that speech directed to topics unrelated to the shopping center would be more likely to impair the motivation of customers to

231. $C f$. Gerald Gunther, Constitutional Law, Cases and Materials, 917 (9th ed. 1975); Mattias Kumm \& Victor Ferrers Commella, What is so Special About Constitutional Rights in Private Litigation?, in The Constitution IN Private Relations: Expanding Constitutionalism, 241, 278 (2005); Glennon \& Novak, supra note 188, at 221, 261.

232. See Marsh v. Alabama, 326 U.S. 501 (1946).

233. See supra Part I.D.

234. See MüLLER, supra note 230, at 242.

235. Marsh, 326 U.S. at 509 (1946).

236. Id. 
buy than speech directed to the uses to which the Center is put." ${ }^{237}$ In this argument, Marshall started from the general importance of freedom of speech and weighed it against "the theoretical possibility of littering," a minor interference with the mall owner's property rights. Marshall completed the argument by stating that the speech's content does not influence the balance under the specific circumstances. $^{238}$ This shows how Marshall used general and specific considerations to determine the relationship between competing rights in the specific case.

Another criterion is the degree to which a right owner for his own advantage has voluntarily opened his private sphere to the public. In Marsh, for example, the Court wrote: "The more an owner, for his advantage, opens up his property for use by the public in general, the more do his rights become circumscribed by the statutory and constitutional rights of those who use it." ${ }^{239}$ Based on this rule, a shopping mall owner is different from a homeowner who has not opened his property to the public, but only to specifically invited guests. ${ }^{240}$ The voluntary exposure of a right to the public for one's own advantage is thus a reason for that right to weigh less in the balancing process. ${ }^{241}$

The factual conditions under which a right is being exercised is an important consideration in the balancing process. This is particularly true for the degree to which interference with one right is necessary, under the specific circumstances of the case, to protect a competing right. For example, Justice Reed argued in his Marsh dissent that because "[a]ppellant ... was free to engage in [distributing religious leaflets] on the [nearby] public highways, without becoming a trespasser on the company's property," ${ }^{242}$ the property right was not outweighed by the freedom of religion. ${ }^{243}$ Conceptually speaking, he argued that it was not necessary for the protection of Marsh's freedoms of speech and religion to limit the company's right to property because speech and religion could just as well be exercised on the nearby public highway.

For the same reason of necessity, the Court in Logan accorded freedom of speech particular weight because available public space in which the speech right might have been exercised was 350 to 500 feet away from the store, whose employment policy the pickets were protesting. ${ }^{244}$ This would have made it difficult for the store's customers, the main addressees of the speech, to see the pickets and notice their speech. It would also have placed the pickets "in some danger by being forced to walk along heavily traveled roads." 245 Justice Marshall

237. Lloyd Corp., Ltd. v. Tanner, 407 U.S. 551, 581-82 (1972).

238. $I d$.

239. Marsh, 326 U.S. at 506 (1946).

240. Amalgamated Food Emp. Union Loc. 590 v. Logan Valley Plaza, Inc., 391 U.S. 308, 324-25 (1968).

241. Barrows v. Jackson, 346 U.S. 249, 262, 267-68 (1953).

242. Marsh, 326 U.S. at 517.

243. Id. at 516 .

244. Amalgamated Food Emp. Union Loc.590, 391 U.S. at 321-22.

245. Id. at 322 . 
argued similarly in his Lloyd dissent where he wrote that, in the specific case, speech outweighed property because speech outside the shopping center would have been ineffective because it was unable to reach the citizens of the city of Portland. ${ }^{246}$ The mall owner's privacy interests, on the other hand, weighed less, because the owner had previously opened up his mall for speech by admitting, for example, presidential candidates to give speeches inside the mall. ${ }^{247}$ This shows how the criterion of necessity and the general rule for ranking speech and property are being combined.

Arguments for weighing property stronger because of the intensity of the damage done to it, and because of its importance in the specific situation, were provided by the dissenters in Logan, who argued that the picketing took place in the supermarket's pickup zone, which is particularly important for a supermarket because it is here that customers load purchased groceries into their cars. ${ }^{248}$ The owner of the supermarket, the argument continued, is more like a homeowner, because even though he has invited the public onto his property, he has done so exclusively for commercial purposes, and not for purposes of political speech. ${ }^{249}$ The Court argued similarly in Lloyd, where it said that shopping malls invite the public for commercial, not for political purposes ${ }^{250}$ and that public sidewalks were right outside the mall so that the protesters' speech was not impeded by having to step outside. ${ }^{251}$

A right's history and purpose are also important factors in determining its weight in the balancing process. In Shelley, for example, a right's historical importance and the combination of different individual rights account for the weight accorded to each right. The Court argued that freedom from discrimination in the enjoyment of property rights weighs particularly heavily because it "was among the basic objectives sought to be effectuated by the framers of the Fourteenth Amendment." ${ }^{252}$ Public interests are not able to outweigh this importance; "Nor may the discriminations . . . be justified as proper exertions of state police power." ${ }^{, 253}$ Neither was Shelley's right to nondiscrimination outweighed by Kraemer's rights to protection of property and freedom of contract: "The Constitution confers upon no individual the right to demand action by the State which results in the denial of equal protection of the laws to other individuals." ${ }^{254}$ As a result, the right to freedom from race-based discrimination, in combination with the right to property, outweigh all other constitutional principles: "Whatever else the framers sought to achieve, it is clear

246. Lloyd Corp., Ltd. v. Tanner, 407 U.S. 551, 580 (1972).

247. Id. at 578 .

248. Amalgamated Food Emp. Union Loc. 590, 391 U.S. at 327.

249. Id. at 332-33, 338.

250. Lloyd Corp., 407 U.S. at 564-65.

251. Id. at 566-67.

252. Shelley v. Kraemer, 334 U.S. 1, 20 (1948).

253. Id. at 21 .

254. Id. at 22 . 
that the matter of primary concern was the establishment of equality in the enjoyment of basic civil and political rights and the preservation of those rights from discriminatory action on the part of the State based on considerations of race or color." 255

In all these cases, one may, and dissenters often did, disagree with the balancing's specific outcomes. Still, the decisions appear as principled applications of the state action doctrine with defensible results after reasonably explained balancing processes.

In many cases, however, the Court did not apply the concepts of horizontalism and proportionality, and instead, focused on exceptions to the state action doctrine, i.e., on conditions under which private actors must be deemed state actors, and private action must be deemed as state action. ${ }^{256}$ The Court has been unable to find principled ways of applying such exceptions, making these cases appear like more or less arbitrary attempts to exempt state law from judicial review. ${ }^{257}$ The Court itself has admitted that it has been unable to develop principled criteria for deciding when a nexus between the state and a private actor is sufficiently significant to consider the private actor a state actor, or to hold the state responsible for private action. Instead, it resorts to a "sifting of facts" and a "weighing of circumstances" on a case-by-case basis in order to "attribute the nonobvious involvement of the State in private conduct its true significance."258 The vagueness of the formula already foreshadows the inconsistencies in its application.

For example, the Court considered a decision to exclude African Americans from voting in party primaries made by the Democratic Party Committee state action, whereas it initially considered the same decision made by the Party's Convention to not be state action, and later decided it was state action. ${ }^{259} \mathrm{~A}$ private shopping mall expelling demonstrators was initially a state actor because of its "striking similarities" with the business block in a company town that functioned just like every other town ${ }^{260}$ however, it was later deemed not to be a state actor, because it was "not performing the customary functions of government," and the speech at issue was not directly related to the mall's purpose. ${ }^{261}$ Additionally, it was not considered a state actor because it was not

255. Id. at 23 .

256. See also GUNTHER, supra note 231, at 98.

257. See also Chemerinsky, supra note 175, at 550; Mattias Kumm \& Victor Ferrers Commella, What is so Special About Constitutional Rights in Private Litigation?, in THE Constitution in Private Relations: Expanding Constitutionalism, 241, 270 (2005); Tushnet, supra note 1, at 183, 185.

258. Burton v. Wilmington Parking Auth., 365 U.S. 715, 722 (1961).

259. See Nixon v. Condon, 286 U.S. 73 (1932); Grovey v. Townsend, 295 U.S. 45 (1935); Smith v. Allwright, 321 U.S. 649 (1944).

260. Amalgamated Food Emp. Union Loc. 590 v. Logan Valley Plaza, Inc., 391 U.S. 308, 317 (1968)

261. Lloyd Corp., Ltd. v. Tanner, 407 U.S. 551, 564 (1972). 
"the functional equivalent of a municipality." ${ }^{262}$ Such inconsistencies make the Court's applications of exceptions to the state action doctrine appear like arbitrary attempts to exempt state law from federal judicial review. The Court itself seems to point in that direction when it argues that its main purposes, in applying the state action doctrine, are to preserve "an area of individual freedom by limiting the reach of federal law and federal judicial power," and to make federal courts "respect the limits of their own power as directed against state governments and private interests." ${ }^{263}$ Unprincipled exemptions of state law from federal judicial review, however, violate not only the state action doctrine, but also of the Supremacy Clause, which makes every law, including every state law, subject to the Constitution, and thus to federal judicial review. ${ }^{264}$ Moreover, the Court's practice of limiting the reach of federal law and federal judicial power seems to rather limit individual freedom than to promote it, because it protects the freedom of the stronger at the expense of the weaker, the freedom of the violator at the expense of the victim. In the words of Friedrich Müller: "Between the weaker and the stronger it is freedom that oppresses and the law that frees."

It is, thus, more than time for a more principled application of the US state action doctrine.

\section{B. More Principled Solutions with Horizontalism and Proportionality}

The application of the concept of horizontalism in combination with the proportionality test would lead to a more principled application of the US state action doctrine. I want to demonstrate that by applying both concepts to the state action cases that I have analyzed above.

In the White Primary Cases, for example, the state law giving private political parties the opportunity to exclude African Americans from party primaries is a state act that strikes a balance in favor of the parties' right to self-determination at the expense of African Americans' rights to vote and to not be discriminated against on the basis of race. The concept of horizontalism requires that this state act remains within constitutional limits. The proportionality test may look like this: (i) Suitability: Authorizing the Democratic Party or the Jaybirds to exclude African Americans from their elections is suitable to protect these private actors' right to self-determination; (ii) Necessity: To protect the private actors' selfdetermination, there is no less invasive means than authorizing them to engage in whatever exclusion they see fit, including race-based exclusion; (iii) Proportionality in the narrower sense: In light of the fact that excluding African

262. Hudgens v. N.L.R.B., 424 U.S. 507, 520-21 (1976).

263. Lugar v. Edmondson Oil Co., Inc., 457 U.S. 922, 936-37 (1982).

264. See Joseph Story, Comment aries on the Constitution of the United States: with A PRELIMINARY REVIEW OF THE CONSTITUTIONAL HISTORY OF THE COLONIES AND STATES BEFORE THE Adoption of the Constitution, Vol. II, $\S \S 1837,1842$ (Thomas M. Cooley ed., 4th ed., 1873).

265. MüLLER, supra note 230, at 150. 
Americans from party primaries practically means excluding them from the vote in general elections, this strong interference with the important rights to vote and to not be discriminated against on the basis of race cannot be justified with preventing a slight interference with a private actor's less important freedom to engage in race-based discrimination. It should thus be concluded that interpreting and applying the state law as authorizing the exclusion of African Americans from party primaries violates African Americans' rights to vote and to nondiscrimination and is unconstitutional.

In the Shopping Mall Cases, the enforcement of trespass law against protesters is a state act that strikes a balance in favor of the mall owner's property right at the expense of the protesters' freedom of speech. Again, horizontalism requires that the balance remain within the limits set by the Constitution. Making the protesters leave the mall may be suitable and necessary to protect the mall owner's property, including his right to determine who enters the mall. It could also be proportionate in the narrower sense if the protesters could exercise their freedom of speech just as effectively on public sidewalks right outside the mall. It would not be proportionate in the narrower sense, however, if, for lack of alternatives, the only available place to effectively engage in speech would be inside the mall. In that case, the slight interference with the less important right to commercially used property through the theoretical possibility of littering or other disturbances of commercial activities would be outweighed by the strong interference with the important right to speech by making effective speech impossible. Further reasons for this relationship between property and speech are two rules previously established by the Court: (i) The more one opens up her property to the public for her own advantage, the more do her rights become circumscribed by the statutory and constitutional rights of those who use the property; and (ii) the historical and political importance of speech. ${ }^{266}$ The result would be different for a private homeowner. Her rights to property and privacy would outweigh a guest's rights to speech and non-discrimination because the homeowner's important rights to property and privacy would not have been weakened by a voluntary act of opening private property up to public access for personal advantages. By contrast, a guest's access to a private home would be less important for the effective exercise of the important rights to speech and nondiscrimination than would be the access to, for example, a shopping mall.

The balancing would be more difficult if, for example, a private club, such as Moose Lodge, ${ }^{267}$ had opened up its property to the public for commercial purposes, but only to the limited public of admitted club members and their guests. The club's property right would weigh less than the homeowner's but more than the restaurant's. It could still be outweighed by the African American guest's right to non-discrimination because the latter is a historically important right that is strongly interfered with because of the high degree of humiliation caused by a request to leave the club's property. However, I will admit that other evaluations might be defensible depending on how important one considers the

266. Marsh v. Alabama, 326 U.S. 501, 506 (1946).

267. See Moose Lodge No. 107 v. Irvis, 407 U.S. 163 (1972). 
right to non-discrimination on the one hand and the right to property on the other and, of course, on the circumstances of the specific case. The argument shows that the final decision of where exactly to strike the balance and why is subjective. Still, the proportionality test makes the decision more reasonable because it forces the judge to be open about her reasons and no longer permits hiding behind entanglement considerations that are supposed to explain whether or not the state is responsible for a private actor's discriminatory action. Horizontalism and the proportionality test clarify that at issue is the constitutionality of a state actor's balancing decision, not the degree of entanglement between the state and a private actor.

Finally, in the Judicial Enforcement Cases, horizontalism would identify the judicial enforcement of state contracts law, libel law, or inheritance law as the relevant state act. The proportionality test would examine its as-applied constitutionality by weighing the involved freedoms of contract, rights to property, rights to non-discrimination, freedom of speech, protection of reputation, and freedom of testation against each other in a way that would apply existing rules of balancing or develop new ones.

\section{CONCLUSION}

The Court's application of the state action doctrine is characterized by the Court's focusing on exceptions according to which it tries to decide whether the nexus between the government and a private actor is close enough to consider the private actor a state actor. Many of the Court's state action decisions are inconsistent and even unreasonable because the Court has been unable to find criteria that would allow the exceptions' principled application. My analysis of some of the Court's major state action decisions has demonstrated that the German concepts of horizontalism and proportionality would require examining the constitutionality of state law as applied in private relationships, and that this would require balancing the competing individual rights and other constitutional principles that are being touched upon by the relevant state acts. The proportionality test provides the framework for a principled balancing and requires that the interference with an individual right or other constitutional principle is suitable, necessary, and proportional in the narrower sense to achieve the goal that the state act aims at. The Court has already applied horizontalism and the proportionality test in many of its state action decisions, and its consequent application would lead to reasonable results in all state action cases. Even though the proportionality test is not an objective way of deciding, it forces the Court to be transparent about the reasons for its decisions. That would be important progress compared with the Court's inconsistent application of the US state action doctrine today. 